\title{
Use of Centrality Metrics to Protect Wildlife Ecology and Habitat Connectivity Analysis
}

\author{
Huriye Simten SÜTÜNÇ \\ Siirt University, Landscape Arhitecture, Kezer Campus, Siirt, TURKEY \\ Corresponding Author: simten.sutunc@siirt.edu.tr
}

Received Date: 23.02 .2021

Accepted Date: 18.09.2021

\begin{abstract}
Aim of study: Aim of this study was to conduct a habitat connectivity analysis using centrality metrics to protect the regional wildlife-habitat connections of the Siirt landscape, and to ensure the continuity of ecological flows in the landscape.

Area of study: Increasing urbanisation trend in recent years and human impact on natural resources cause the diversity in Siirt landscape to be negatively affected. Centrality metrics were sampled in Siirt landscape in terms of re-establishing and maintaining the connectivity in the landscape.

Material and methods: Environmental Plan was used to define the core areas. Land cover/land uses were digitised using Geographical Information Systems. Firstly, landscape connectivity corridors defined with least-cost-path and secondly, current flow centrality was used with circuit theory.

Main results: The core area with the strongest flow centrality was forest, with a value of 14.6 , and the core area with the weakest flow centrality was marsh at 8.23. The core areas that establish the easiest and strongest connection with each other are wetland-pasture, pasture-geologically reserved area, and pastureecological area.

Highlights: The greater the distance between core areas, the weaker the degree of connectivity between species and habitats. Increasing the distance between core areas negatively affects the ecological flow.

Keywords: Centrality Metrics, Circuit Theory, Habitat Connectivity, Least-Cost-Path, Ecological
\end{abstract} Flow.

\section{Yaban Hayatı Ekolojisini Korumak Amacıyla Merkezlik Metriklerinin Kullanılması ve Habitat Bağlantılılık Analizi}

$\ddot{O} \mathbf{z}$

Çalışmanın amacı: $\mathrm{Bu}$ çalışmanın amacı. Siirt peyzajının bölgesel yaban hayatı ve habitat bağlantılarını korumak ve peyzajdaki ekolojik akışların sürekliliğini sağlamak için merkezlik metriklerini kullanarak bir habitat bağlantı analizi yapmaktır.

Çalışma alanı: Son yıllarda artan kentleşme eğilimi ve doğal kaynaklar üzerindeki insan etkisi Siirt coğrafyasındaki çeşitliliğin olumsuz etkilenmesine ve parçalanmanın artmasına neden olmaktadır. Peyzajdaki bağlantının yeniden kurulması ve sürdürülmesi açısından merkezlik metrikleri Siirt peyzajında örneklenmiştir.

Materyal ve yöntem: Siirt peyzajında çekirdek alanları tanımlamak için 1/100.000 ölçekli Çevre Düzeni Planı kullanılmıştır. Bu plandaki tüm arazi örtüsü/arazi kullanımları Coğrafi Bilgi Sistemleri kullanılarak sayısallaştırılmıştır. En düşük maliyetli yol yöntemi ile peyzaj bağlantı koridorları tanımlanmış, merkezlik metrikleri için de devre teorisi kullanılmıştır.

Temel sonuçlar: Siirt peyzajında en güçlü akış merkeziliğine sahip çekirdek alan 14.6 değeriyle orman, en zayıf akış merkeziliğine sahip çekirdek alan 8.23 ile bataklıktır. Birbiriyle en kolay ve en güçlü bağlantıyı kuran çekirdek alanların sulak alan-mera, mera-jeolojik açıdan sakıncalı alan ve mera-ekolojik alan olduğu görülmüştür.

Araştırma vurguları: Çekirdek alanlar arasındaki mesafe ne kadar büyükse, türler ve habitatlar arasındaki bağlantı derecesi o kadar zayıftır. Çekirdek alanlar arasındaki mesafenin artması ekolojik akışı olumsuz etkilemektedir.

Anahtar Kelimeler: Merkezlik metrikleri, Devre teorisi, Habitat Bağlantılılığı, En Düşük Maliyetli Yol, Ekolojik Akış. 


\section{Introduction}

Wildlife ecology is the use of ecological principles to study wildlife species (Rachlow, 2008). Although the term "wildlife" has been used with different meanings in the past, today the term also includes all terrestrial vertebrates and invertebrates. Fish and other aquatic species are not considered within the scope of wildlife. Individual organisms and their relationships with the environment, the interaction of individuals in a population, community dynamics and structure are all within the scope of wildlife ecology. More recently, this scope has been expanded to include interaction of wildlife with ecosystem processes and the genetics of populations (Rachlow, 2008). The most basic concept of wildlife ecology is habitat. Habitat has been used both in organismspecific and terrestrial sense. Wildlife ecologists, on the other hand, defined the habitat as the place where the species carries out all its vital activities (Rachlow, 2008). Habitat corridors allow movement between isolated populations and increase genetic diversity. Corridors between habitats help the dispersal of species and ecological flow, while minimising interactions between wildlife and human. In recent years, with increase in the use of geographic information systems technology and the expansion of its scope, the distribution of wildlife species and their habitats has become analysable and mappable.

Our planet is undergoing constant change and transformation. Approximately 17\% of the land on the earth's surface has been converted to urbanisation and agriculture, and $56 \%$ is characterised by rural, urban, and suburban use. Only approximately only $26 \%$ can be defined as large wild areas (Locke et al., 2019). Although these three usage types are considered separately from another, they all require ecological connections within and between them. In landscape ecology, connectivity (corridors) is used to describe the structural and functional continuity of a landscape in space and time (Forman \& Godron, 1986). The habitat connection at the landscape level plays an important role in the viability of the population by facilitating movement, migration, dispersal and recolonisation by maintaining gene flow (Saura
\& Pascual-Hortal, 2007). In particular, the spatial configuration and distribution of habitats at the landscape scale determines the survival and persistence of species (Xun et al., 2014). Movement of individuals between landscapes can affect many ecological processes, from individual survival to the viability of populations as well as metapopulations, community dynamics, ecosystem resilience and wider biodiversity. Species distributions and variations depend on the mobility of the species (e.g., in response to climate change) and still mediate landscape structure. Loss of connectivity, mainly caused by the unprecedent expansion of anthropogenic infrastructure, is an increasingly central driver of the global biodiversity crisis. Therefore, a need for consensus on what connection means and how to measure it. One of the ways to look at landscape is to examine the structural connectivity of the landscape, regardless of any biological or behavioural characteristics of organisms interacting with it (Kindlmann \& Burel, 2008; Tischendorf \& Fahrig, 2000). Alternatively, Taylor et al., (1993), used the term "landscape connectivity" to describe the degree to which the landscape facilitates or inhibits movement between source patches. The later derivative of this term is the concept of "functional connectivity", which focuses on the landscape from the perspective of the species and thus on the outcome of interactions between individuals and landscape structures according to their needs, perceptions, and reactions. This term, which is closely tied to the "movement ecology" paradigm, that focuses on individuals and their reactions to their environment (Allen \& Singh, 2016; Fraser et al., 2018; Nathan et al., 2008), has become dominant in landscape ecology. To summarise, structural connectivity represents a part of the landscape that is connected through corridors or other structures. Functional connectivity includes speciesspecific situations and their interaction with landscape structure. The functional connectivity is therefore the real connectivity from a species perspective. However effectively maintaining the connectivity between landscapes and species requires an assessment of how landscape composition 
and structure affect ecological and evolutionary processes at a wide variety of levels of biological organisation (Carroll et al., 2012; Rayfield et al., 2011).

In this study, a connectivity analysis was conducted using graph theory, which describes the relationship between movements of species in the landscape and its habitats and provides complementary information for both corridor design and regional conservation planning (D'Elia et al., 2020; McRae, 2012; McRae et al., 2008; McRae \& Kavanagh, 2011). In this theory, a graph is a set of nodes where node pairs can be connected by edges representing functional connections between nodes (Urban et al., 2009). Weights can be assigned to edges that represent a feature such as habitat quality. A series of nodes connected by edges form a path. While the landscape pattern has highly abstracted structures, the graphics can reveal more delicate aspects of the landscape structure that may not be otherwise noticed. In graph theory and network analysis, centrality metrics identify the most important corners in a graph. Centrality metrics answer the question "what characterises an important node?".

The answer is given as a real- valued function at the vertices of a graph, and the values generated here are expected to provide a ranking that identifies the most important nodes (Newman, 2010). In this study, the landscape corridors in the landscape of Siirt were defined, and the flow centrality along the networks forming the corridors was calculated. Current flow centrality provides a measure of how important a connection or core area is in keeping the public network connected. In the landscape of Siirt, the core areas with the strongest flow centrality were forests and pastures, with a value of 14.6, while the core area with the weakest flow centrality was marshes at 8.23. Centrality metrics defined common networks containing alternative connections that would provide more flexibility in planning. This method can be used in habitat connectivity analysis and in planning studies aimed at protecting regional habitat connectivity in the broadest sense.

\section{Material and Methods \\ Study Area}

Increasing urbanisation trends in recent years and human impact on natural resources have had a negative effect on diversity in the Siirt landscape and caused increased fragmentation. Therefore, centrality metrics are sampled in the Siirt landscape in terms of re-establishing and maintaining the connectivity in the landscape. Siirt Province is located in the south-eastern Anatolia Region of Turkey at $37.9293^{\circ}$ North latitude and $41.9413^{\circ}$ East longitude. Siirt stands out for its agricultural identity due to the characteristics of its region. However, there are different land cover/land uses in the province (Figure 1).

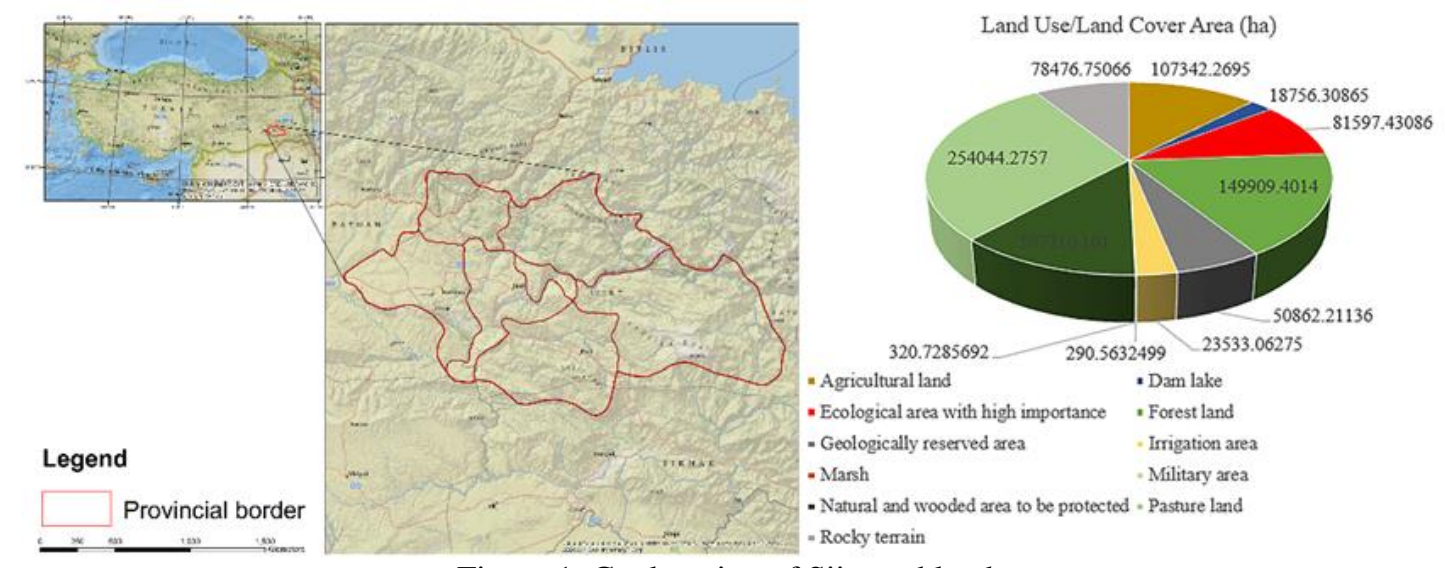

Figure 1. Geolocation of Siirt and land uses 


\section{Landscape Connectivity and Centrality Metrics}

A 1/100.000 scaled EP was used to define the core areas in the Siirt landscape. In this plan and within the borders of Siirt, all land cover/land uses were digitised using Geographical Information Systems (GIS), and the core areas to be used in the next stages were created through the Patch Analyst/PatchGrid (Rempel, 2015). Centrality metrics were used to determine the answer to which core areas in the Siirt landscape had stronger connectivity and which core areas had more continuous ecological flow (McRae et al., 2008). The calculation of centrality metrics took place in two stages. In the first stage, the landscape corridors between core areas were determined using the least-cost-path (LCP) and Euclidean distance (ED) methods (McRae \& Kavanagh, 2011) and in the second stage, the flow centrality between these corridors was calculated with centrality metrics (McRae, 2012). The Linkage Pathways (McRae \& Kavanagh, 2011) software was used to determine the corridors between core areas. The software uses core area data and resistance raster to identify and map corridors between core areas. Each cell in the resistance map is associated with a value that reflects the energetic cost (difficulty and risk of death) of moving through that cell. Resistance values are typically determined by cell characteristics such as land cover or settlement density, together with species-specific landscape resistance patterns. Cost-weighted-distance analyses produce accumulated aggregate motion resistance data as species move away from specific core areas.

Linkage Pathways (McRae \& Kavanagh, 2011) uses ArcGIS and Python scripts to identify adjacent core areas and identify the lowest-cost corridors between them. It then mosaics the corridors to create a single composite corridor map. The result shows the relative value of each grid cell in establishing connections between core areas, helping to determine which paths meet more or fewer features that facilitate or inhibit movement between core areas. After determining the corridors, the centrality of the flow between them and the identification of which core area would strongly support this flow were calculated using Centrality Mapper (McRae, 2012). This software analyses the connection networks and calculates the "current flow centrality" throughout the networks. Current flow centrality is a measure of the importance of a connection keeping the public network connected. This is circuit theory (Cushman \& Landguth, 2010; Cushman et al., 2006; D'Elia et al., 2020; Dyer et al., 2010; Hanks \& Hooten, 2013; Lookingbill et al., 2010; McRae, 2006; McRae \& Beier, 2007; McRae et al., 2008; Owen-Smith et al., 2010; Rayfield et al., 2011; Saura \& Rubio, 2010; Urban et al., 2009) In this study, the Circuitscape v4.0.5 software was used for easy application of circuit theory. Circuitscape is an open-source software that uses circuit theory to model connectivity in heterogeneous landscape. Its common applications include modelling movement and gene flow of plants and animals, as well as identifying areas important for connectivity conservation. In connection with Circuitscape, Linkage Mapper is a toolbox that includes six tools -only Linkage Pathways and Centrality Mapper used in this study- can be used for predicting wildlife corridors in landscape. These toolboxes use Circuitscape to execute circuit theory that is the most important for keeping a network connected. According to Dutta et al., (2016), Centrality Mapper treats each core as a node, and each connection as a single resistor and assigns a resistance equal to the costweighted-distance of the corresponding lowest-cost corridor. It repeats all the core filed pairs, injecting 1 ampere (A) of current into a core filed. It then maps the cumulative current flow by summing the current flow for each core and connection. This indicates the importance of each connection in maintaining connectivity across the entire core network and can be thought of as a measure of connectivity and core centrality.

\section{Results and Discussion \\ Landscape Connectivity}

Considering the scale of the study, although the Tigris River passing through the provincial boundaries and the streams feeding it are dominant, the highway and the 
first-degree road are within the scope of the landscape connectivity corridors. Habitat, channel, and resource functions, which are among the characteristics of corridors, vary in parallel with high connectivity that enables species to move easily along the corridor. The less space per unit length along the corridor, the higher the connectivity. In addition to the number of voids, degree of aggregation and the length of each cavity are ecologically important. Clustered spaces serve as a series of stepping stones in the corridor system (Forman, 1983; Forman, 1995; Forman \& Godron, 1986; Shi et al., 2020). When the connectivity in the Siirt landscape is evaluated, the core areas that establish the easiest and strongest connection with each other are wetland-pasture, pasturegeologically reserved area, and pastureecological area. The distance values of these fields to each other are 0 (zero). When evaluated, according to LCP lengths, the core areas that required the most interaction to establish a connection were the wetland, protected area, pasture, geologically reserved area, and marsh. This indicates that there is less space between these areas (Figure 2). Shorter LCP lengths have greater current flow centrality.

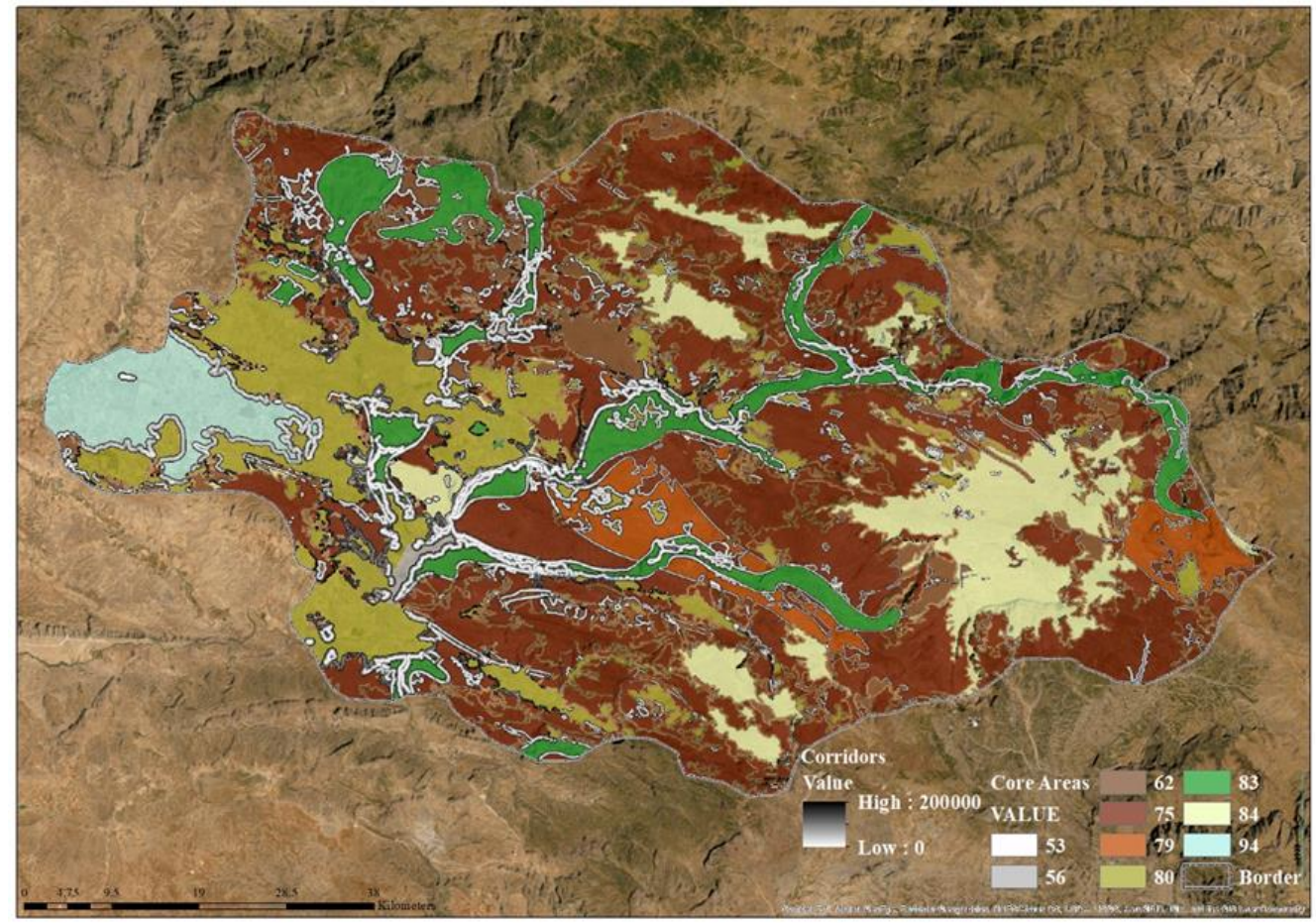

Figure 2. Landscape connectivity corridors

Core areas with a greater distance between them are the most remote and most difficult to connect; agricultural landirrigation area, marsh-forest, rocky terrainirrigation area, marsh-protected area, marshagricultural area, and marsh-rocky terrain. The stronger the connection between core areas in the landscape of Siirt, the more easily ecological flow occurs. This makes it easier for species to interact better with the landscape and contributes to heterogeneity.

\section{Centrality Metrics and Habitat Connectivity Analysis}

Opening natural habitats/landscapes to human use, narrowing the habitats of species, disrupting landscape connectivity and increasing the level of habitat fragmentation are among the greatest threats to biodiversity and functional ecosystems (Fahrig, 2003). Metapopulations are spatially structured populations of species, and the persistence of these populations is strongly associated with landscape connectivity. When landscape connectivity is low, subpopulations are 
isolated and recovery following local extinction is less likely, as successful recolonisation depends on the dispersal of species throughout the landscape (Hanski \& Ovaskainen, 2003). On the other hand, even if habitat fragmentation has reduced the number of habitat patches in the landscape, species moving from one patch to another can reach large areas of habitat with a sufficiently high level of connectivity (Lundberg \& Moberg, 2003).

In graph theory, measurements with centrality metrics consider paths between all possible pairs of nodes to assess the role of each node in mediating ecological flow Figure 2. Centrality metrics analysis (Borgatti, 2005; Bunn et al., 2000; Carroll et al., 2012). Node loss occurring in most of the roads in the networks that provide ecological flow disproportionality increases the distance or transition time between networks, just as the connections of the chain break. Within the framework of centrality metrics, the current centrality of flow among the core areas in the Siirt landscape was forest. The strongest flow was between the geologically reserved area and agricultural area with the values of 3.96 and14.6, while the weakest was marshes with the value of 8.23 (Figure 3). When evaluated in terms of flow connections, the weakest flow centrality was seen between the rocky terrain and the irrigation area (0.74).

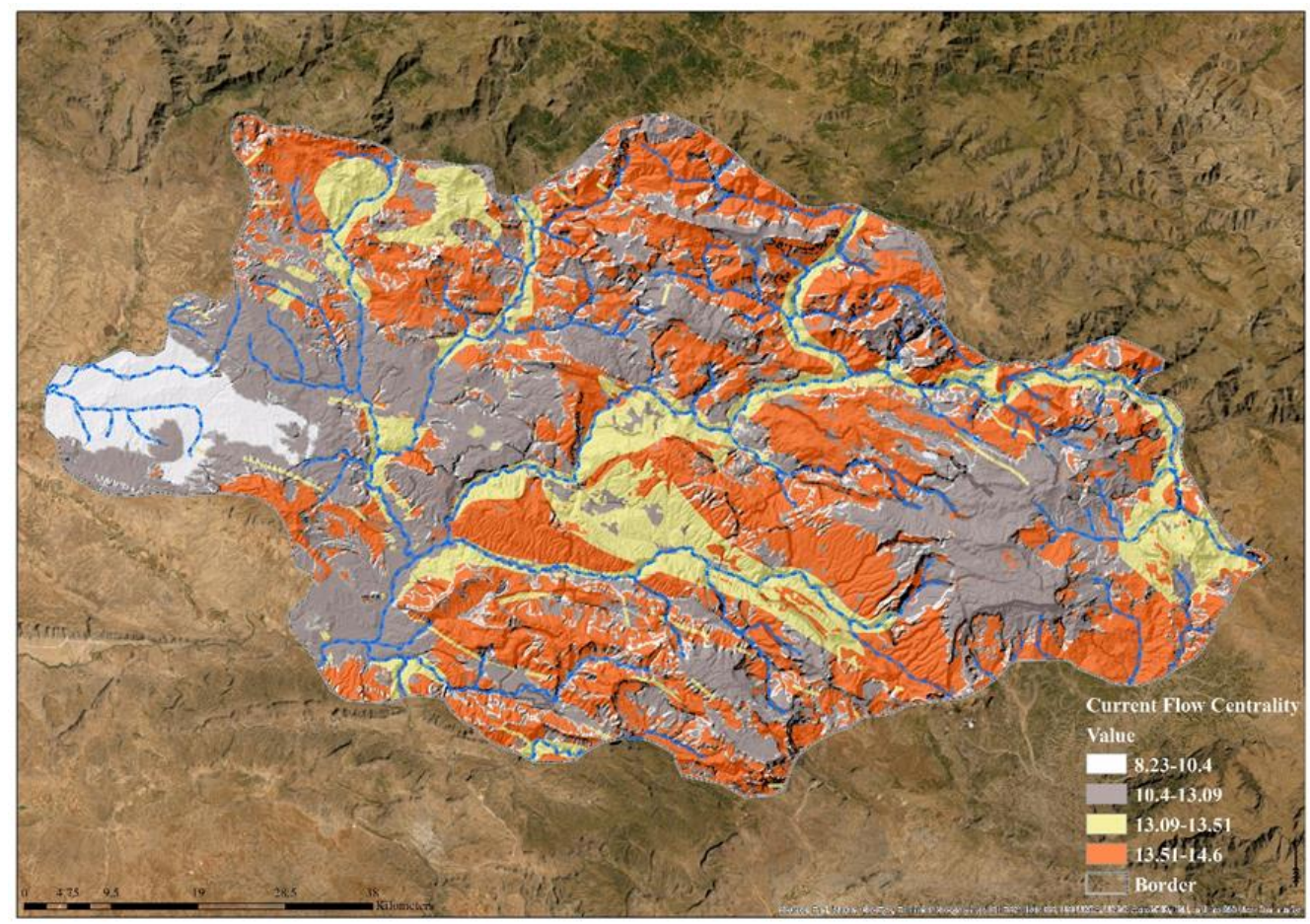

Figure 3. Centrality metrics analysis

In the connectivity analysis, the current flow centralities of the wetland-pasture, pasture-geologically reserved area, and pasture-ecological area, where the ED values between them were 0 (zero) and which could easily connect with each other, were calculated as 3.41, 3.18, and 2.56, respectively. The current flow centres of the agricultural area-irrigation area, marshforest, rocky terrain-irrigation area, marshprotected area, marsh-agricultural area, and marsh-rocky terrain, which had the greatest ED values, were calculated as $0.92,2.10$, $0.74,2.11,2.11$, and 2.14 , respectively. In the connectivity analysis, the current flow centrality values of the core areas with similar ED and LCP values close to each other were also close together.

Another feature that draws attention in both maps is that the connections are concentrated in the northwest of the area, taking into account certain core areas. Of 
course, it can be assumed that topographical features contribute to this, but the concentration should not be attributed entirely to this. The first reason may be the index values of the areas provided as input to the software before the connectivity analysis, and the second is the distance between them. When the results of the analyses with the connectivity and centrality metrics are examined, it is seen that the core areas with the lowest index value and the core areas with the highest index value show high ED and LCP values. In contrast, the ED and LCP values of the core areas whose core area index values are close to each other are also low. This appears to be a factor affecting the ecological flow between habitats and species (Allen \& Singh, 2016; Fraser et al., 2018; Nathan et al., 2008). There seems to be some proportionality between the ED and LCP values and the current flow centrality values.

Core areas with high distance values have low current flow centrality. This means that the shorter the distance between core areas, the stronger and easier the ecological flow between species and habitats. In contrast, the longer the distance values, the more difficult the ecological flow between species and habitats. On the other hand, connections concentrated in a certain part of the field indicate the presence of clustered spaces (Forman, 1983; Forman, 1995; Forman \& Godron, 1986; Shi et al., 2020) that serve as stepping stones. It can be concluded that the marsh, wetland, protected area, ecological area, rocky terrain, geologically reserved area, and irrigation area serve as stepping stones in the landscape of Siirt. It should also not be overlooked that these areas are not fragmented/relatively fragmented areas.

\section{Conclusions}

Dams and roads built to meet the needs of the population with increasing urbanization trends in recent years have caused fragmentation in the Siirt landscape. With this fragmentation, the connectivity between species and habitats in the landscape was interrupted in parallel. Restoring the connection between species and habitats and maintaining the ecological flow is important not only in Siirt but also on a global scale. In this study, a habitat connectivity analysis was conducted using centrality metrics to assess ecological flow between species and habitats. According to analysis results;

-The greater the distance between core areas in the Siirt landscape, the weaker the degree of connectivity between species and habitats.

-Increasing the distance between core areas negatively affected the ecological flow.

-The current centrality of flow between the core area pairs (rocky terrain-irrigation area) having similar index values was lowest. In contrast, the current centrality of flow between pairs of core areas (marsh-rocky terrain) with the lowest and highest index value was high.

-In the landscape of Siirt, the few and unfragmented areas (ecological area, marsh, protected area, geologically reserved area, wetland, rocky terrain and irrigation area) served as stepping stones.

Items that can be considered among the recommendations of this study are explained in the following paragraphs. Landscape connectivity is the role of landscape structure in promoting or hindering the separation and movement of ecological flows within a landscape, reflecting the responses of ecological processes to the landscape pattern. Therefore, decision makers and practitioners will need to act more proactively to evaluate and improve the extent to which habitat patches scattered throughout the landscape function as stepping stones that facilitate distribution among otherwise isolated habitat areas.

Each different-sized patch/habitat has different effects on the landscape. While large and medium-sized habitats play an important role in maintaining the overall connectivity in the landscape, small habitats are used as "stepping stones" to improve connectivity in local areas. For the construction of ecological networks, and their improvement and effective connection to the landscape through corridors, conservation studies should choose methods with strong implementation direction, carry out studies aimed at the continuation of ecological flow between species and habitats, formulate and implement upper-scale planning strategies, and manage the work to be done by different professional disciplines. 
It should not be overlooked that conservation and maintenance of the connectivity in the landscape for species and habitats may be required not only in core areas but also in areas outside the core areas, and different strategies may need to be applied.

\section{Acknowledgements}

This study has not been supported by any institution.

\section{Ethics Committee Approval N/A}

\section{Peer-review}

Externally peer-reviewed.

\section{Author Contributions}

This study has been carried out by the author only and the author has been read and agreed to the published version of manuscript.

\section{Conflict of Interest}

The author have no conflicts of interest to declare.

\section{Funding}

The author declared that this study has received no financial support.

\section{References}

Allen, A. M. \& Singh, N. J. (2016). Linking movement ecology with wildlife management and conservation. Frontiers in Ecology and Evolution 3(155). doi:10.3389/fevo.2015.00155.

Borgatti, S. (2005). Centrality and Network Flow. Social Networks, 27, 55-71. doi:10.1016/j.socnet.2004.11.008.

Bunn, A. G., Urban, D. L. \& Keitt, T. H. (2000). Landscape connectivity: A conservation application of graph theory. Journal of Environmental Management, 59(4), 265-278. doi:https://doi.org/10.1006/jema.2000.0373.

Carroll, C., McRae, B. H. \& Brookes, A. (2012). Use of linkage mapping and centrality analysis across habitat gradients to conserve connectivity of Gray wolf populations in Western North America. Conservation Biology, 26(1), 78-87.

Cushman, S. A. \& Landguth, E. (2010). Scale dependent inference in landscape genetics.
Landscape Ecology, 25, 967-979. doi:10.1007/s10980-010-9467-0.

Cushman, S. A., McKelvey, K. S., Hayden, J. \& Schwartz, M. K. (2006). Gene flow in complex landscapes: testing multiple hypotheses with causal modeling. The American Naturalist, 168(4), 486-499. doi:10.1086/506976.

D’Elia, J., Brandt, J., Burnett, L. J., Haig, S. M., Hollenbeck, J., Kirkland, S. \& Young, R. (2020). Applying circuit theory and landscape linkage maps to reintroduction planning for California Condors. Plos One, 14(12), e0226491. doi:10.1371/journal.pone.0226491.

Dutta, T., Sharma, S., McRae, B. H., Roy, P. S. \& DeFries, R. (2016). Connecting the dots: mapping habitat connectivity for tigers in central India. Regional Environmental Change, 16(1), 53-67. doi:10.1007/s10113015-0877-z.

Dyer, R. J., Nason, J. D. \& Garrick, R. C. (2010). Landscape modelling of gene flow: improved power using conditional genetic distance derived from the topology of population networks. Mol Ecol, 19(17), 3746-3759. doi:10.1111/j.1365-294X.2010.04748.x.

Fahrig, L. (2003). Effects of habitat fragmentation on biodiversity. Annual Review of Ecology, Evolution, and Systematics, 34(1), 487-515.

doi:10.1146/annurev.ecolsys.34.011802.1324 19.

Forman, R. T. T. (1983). An ecology of the landscape. BioScience, 33(9), 535-535. doi:10.1093/bioscience/33.9.535.

Forman, R. T. T. (1995). Land mosaics: The ecology of landscapes and regions Cambridge. New York: Cambridge University Press.

Forman, R. T. T. \& Godron, M. (1986). Landscape ecology. New York: Wiley.

Fraser, K. C., Davies, K. T. A., Davy, C. M., Ford, A. T., Flockhart, D. T. T. \& Martins, E. G. (2018). Tracking the conservation promise of movement ecology. Frontiers in Ecology and Evolution, 6(150). doi:10.3389/fevo.2018.00150.

Hanks, E. M. \& Hooten, M. (2013). Circuit theory and model-based inference for landscape connectivity. Journal of the American Statistical Association, 108(501), 22-33. doi:10.1080/01621459.2012.724647.

Hanski, I. \& Ovaskainen, O. (2003). Metapopulation theory for fragmented landscapes. Theoretical Population Biology 64(1), 119-127. doi:10.1016/s00405809(03)00022-4. 
Kindlmann, P. \& Burel, F. (2008). Connectivity measures: A review. Landscape Ecology, 23(8), 879-890. doi:10.1007/s10980-0089245-4.

Locke, H., Ellis, E., Venter, O., Schuster, R., Ma, K., Shen, X. \& Watson, J. (2019). Three global conditions for biodiversity conservation and sustainable use: An implementation framework. Proceedings of the National Science Council, 6. doi:10.1093/nsr/nwz136.

Lookingbill, T. R., Gardner, R. H., Ferrari, J. R. \& Keller, C. E. (2010). Combining a dispersal model with network theory to assess habitat connectivity. Ecological Applications, 20(2), 427-441. doi:https://doi.org/10.1890/090073.1.

Lundberg, J. \& Moberg, F. (2003). Mobile link organisms and ecosystem functioning: Implications for ecosystem resilience and management. Ecosystems, 6(1), 0087-0098. doi:10.1007/s10021-002-0150-4.

McRae, B. H. (2006). Isolation by resistance. Evolution, 60(8), 1551-1561. doi:https://doi.org/10.1111/j.00143820.2006.tb00500.x.

McRae, B. H. (2012). Centrality Mapper Connectivity Analysis Software. Retrieved from http://www.circuitscape.org/linkagemapper.

McRae, B. H. \& Beier, P. (2007). Circuit theory predicts gene flow in plant and animal populations. Proceedings of the National Academy of Sciences, 104(50), 19885-19890. doi:10.1073/pnas.0706568104.

McRae, B. H., Dickson, B. G., Keitt, T. H. \& Shah, V. B. (2008). Using circuit theory to model connectivity in ecology, evolution, and conservation. Ecology, 89(10), 2712-2724. doi:10.1890/07-1861.1.

McRae, B. H. \& Kavanagh, D. M. (2011). Linkage Mapper Connectivity Analysis Software. Retrieved from http://www.circuitscape.org/linkagemapper.

Nathan, R., Getz, W. M., Revilla, E., Holyoak, M., Kadmon, R., Saltz, D. \& Smouse, P. E. (2008). A movement ecology paradigm for unifying organismal movement research. Proceedings of the National Academy of Sciences, 105(49), 19052-19059. doi:10.1073/pnas.0800375105.

Newman, M. E. J. (2010). Networks: An introduction. New York: Oxford University Press.

Owen-Smith, N., Fryxell, J. M. \& Merrill, E. H. (2010). Foraging theory upscaled: the behavioural ecology of herbivore movement. Philosophical Transactions of the Royal
Society B: Biological Sciences, 365(1550), 2267-2278. doi:10.1098/rstb.2010.0095.

Rachlow, J. L. (2008). Wildlife Ecology. In S. E. Jørgensen \& B. D. Fath (Eds.), Encyclopedia of ecology, 3790-3794. Oxford: Academic Press.

Rayfield, B., Fortin, M. J. \& Fall, A. (2011). Connectivity for conservation: a framework to classify network measures. Ecology, 92(4), 847-858. doi:https://doi.org/10.1890/092190.1 .

Rempel, R. (2015). Spatial ecology programanalysis tools/patch analyst. Ontario, Ontario, United States of America: Queens Press, Ontario Ministry of Natural Resources and Forestry. Retrieved from http://www.cnfer.on.ca/SEP/.

Saura, S. \& Pascual-Hortal, L. (2007). A new habitat availability index to integrate connectivity in landscape conservation planning: Comparison with existing indices and application to a case study. Landscape and Urban Planning, 83(2), 91-103. doi:https://doi.org/10.1016/j.landurbplan.2007 .03 .005 .

Saura, S. \& Rubio, L. (2010). A common currency for the different ways in which patches and links can contribute to habitat availability and connectivity in the landscape. Ecography, 33(3), 523-537. doi:https://doi.org/10.1111/j.16000587.2009.05760.x.

Shi, F., Liu, S., An, Y., Sun, Y., Zhao, S., Liu, Y. \& Li, M. (2020). Spatio-temporal dynamics of landscape connectivity and ecological network construction in Long Yangxia Basin at the Upper Yellow River. Land, 9(8), 265. Retrieved from https://www.mdpi.com/2073445X/9/8/265.

Taylor, P. D., Fahrig, L., Henein, K. \& Merriam, G. (1993). Connectivity is a vital element of landscape structure. Oikos, 68, 571-573.

Tischendorf, L. \& Fahrig, L. (2000). On the usage and measurement of landscape connectivity. Oikos, 90(1), 7-19. doi:10.1034/j.16000706.2000.900102.x.

Urban, D. L., Minor, E. S., Treml, E. A. \& Schick, R. S. (2009). Graph models of habitat mosaics. Ecology Letters, 12(3), 260-273. doi:https://doi.org/10.1111/j.14610248.2008.01271.x

Xun, B., Yu, D. \& Liu, Y. (2014). Habitat connectivity analysis for conservation implications in an urban area. Acta Ecologica Sinica, 34(1), 44-52. doi:https://doi.org/10.1016/j.chnaes.2013.11.0 06. 